International Journal of Psychological Research and Reviews (ISSN:2639-6041)

\title{
Use of Ketamine as a Date Rape Drug: a Systematic Scoping Review
}

\section{Stefania Dermitzaki ${ }^{1}$, Maria Nystazaki $^{2}$}

${ }^{1} \mathrm{RN}$, Faculty of Nursing, National and Kapodistrian University of Athens, Greece; ${ }^{2} \mathrm{PhD}, \mathrm{MSc}, \mathrm{RN}$, 2nd University Psychiatric Clinic, General University Hospital Attikon, Athens, Greece

\section{ABSTRACT}

Background and Objectives: The interdependence of ketamine and rape represent an emerging issue for both the developed and the developing countries. Ketamine is rarely used in human surgery nowadays, but there is a range of traits concerning the aforementioned drug making it the most appropriate one for committing a sexual assault.

Methods: An advanced search in Medline, CINAHL, PsychINFO, Scopus and Cohrane Library and ScienceDirect was conducted. Identified articles were published between 2005 and 2020.

Results: Eight empirical studies were included that comprised the number of victims who had consumed unwillingly ketamine leading to rape.

Conclusion: Ketamine as a rape drug is an emerging issue, the extent of which we do not yet acknowledge. Community based informative programs for the public should be implemented, concerning the hazards following the consumption of ketamine.

Keywords: ketamine, rape, date rape drugs, drug facilitated sexual assault

Abbreviations: Drug Facilitated Sexual Assaults (DFSA), Non, Governmental Organizations (NOGs)

Funding: This research did not receive any specific grant from funding agencies in the public, commercial, or not-for-profit sectors.
*Correspondence to Author:

Maria Nystazaki

Rimini 1 Haidari, Athens, Greece 12462

How to cite this article:

Stefania Dermitzaki, Maria Nystazaki. Use of Ketamine as a Date Rape Drug: a Systematic Scoping Review. In-ternational Journal of Psychological Research and Reviews, $\quad 2021, \quad 4: 52$.

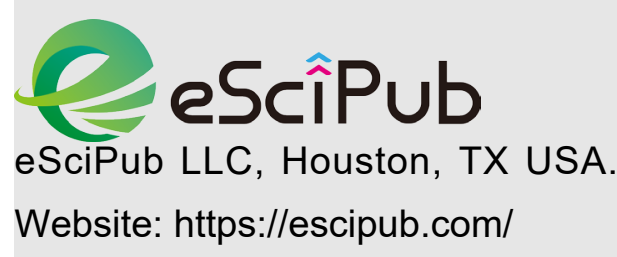




\section{Introduction}

Ketamine [2- (2-chlorophenyl) -2-methylaminocyclohexanone] is a synthetic drug developed in 1962 as an alternative to phencyclidine (PCP). It is one of the most well-known associative anesthetic agents used in clinical practice due to its ability to maintain respiration and blood pressure. Veterinarians use ketamine in order to induce anesthesia to animals, to perform operations, for traveling purposes or to practice euthanasia [1]. Nowadays, ketamine is rarely used in human surgery, but when the patient is in a critical situation, the use of ketamine is necessary due to the effects that this pharmaceutical drug has in the cardiovascular and respiratory system ${ }^{[1,2]}$.

Experimentally, ketamine was first used in prisoners in 1964 and was approved in the United States by the Food and Drug Administration (FDA) in 1970 and consecutively, Ketamine was first used in the battlefield between 1970 and 1975, since it was administrated to soldiers in the Vietnam War for the purpose of military prehospital analgesia and sedation in combat casualties ${ }^{[3,4]}$.

Ketamine's consumption leads to addiction and thus it belongs to the hallucinogenic substances. The cost of ketamine is $\$ 80$ per gram and it can be injected (intravenously or intramuscularly), swallowed or smoked, while most abusers prefer to snort or ingest ketamine. As a drug, ketamine is quite difficult to be produced and hence, "most abusers acquire it through prescription drug diversion" [1]. As an illegal substance, it is known as "special K", "K", "vitamin K", "ket", "purple", "Green", "kit-kat", "keets", "super-acid", "Super K", "jet", "horse trank", "cat 66", "valium" and "tac e tic" $[3,4,5]$.

Due to the fact that ketamine is tasteless, odorless and colorless, it can be easily added in someone's drink for the purpose of a potential sexual assault ${ }^{[1,2]}$. Nowadays, a typical scenario of ketamine use involves the perpetrator pouring a few drops or dropping a pill in the unsuspecting victim's drink in order to anesthetize him/her and then rape him/her ${ }^{1}$. According to WHO "sexual violence is defined as: any sexual act, attempt to obtain a sexual act, unwanted sexual comments or advances, or acts to traffic, or otherwise directed, against a person's sexuality using coercion, by any person regardless of their relationship to the victim, in any setting, including but not limited to home and work. Sexual violence includes rape, defined as physically forced or otherwise coerced penetration - even if slight - of the vulva or anus, using a penis, other body parts or an object" [6].

Ketamine is one of the "club-drugs". Most people use club drugs because they want to feel "high", more energetic or to reduce suspension. As a result, some people try to exploit this situation by using club drugs in entertainment venues to get closer to others and sexually harass unsuspecting victims, who usually do not remember what happened during or/ and after the incident ${ }^{[1,7]}$.

Sexual assault or rape is one of the most important crimes occurring all over the world and, subsequently, "Drug Facilitated Sexual Assaults [DFSA] are defined as offences in which victims are subjected to non-consensual sexual acts, while they are incapacitated or unconscious due to the effects of alcohol and /or drugs $^{2}$ and they are therefore prevented from resisting or they are unable to consent" [7]. It is important to mention that $75 \%$ of all rapes committed occurred the same day the perpetrator got to meet the victim accompanied by the consumption of alcohol and/or drugs [8].

Undoubtedly, the use of ketamine as a date-rape is a raising problem, the extent of which we do not know exactly [9]. The present scoping review presents a synthesis of empirical data on the relationship between ketamine and its use as a rape-drug.

\section{Material and Methods}

2 Lee et al agree that the most common way to render unconscious someone by the use of ketamine is the pill (2018).

${ }^{1}$ The victim experiences rapidly amnesia, especially 15 minutes after the consumption of the drug. IJPRR:https://escipub.com/international-journal-of-psychological-research-and-reviews/ 
The present Systematic Scoping Review presents a synthesis of empirical data on the relationship between ketamine and its use as a rape-drug. An advanced search in Medline, CINAHL, PsychINFO, Scopus and Cohrane Library and ScienceDirect was conducted between October 2020 and January 2021 by two researchers [S.D and M.N]. The following search words were used "ketamine", "drug", "rapedrug".

The following inclusion criteria for the articles were set a] an empirical quantitative study b] published in the English language, in a peerreviewed journal between 2005 and 2020. Moreover, the focus of the present review was on the use of ketamine solely as a rape-drug and not as a substance of abuse or dependence. All studies reporting voluntary drug consumption by victims were excluded.

One hundred and ninety four abstracts were extracted while conducting the search and after excluding duplicated ones, one hundred and eighty three abstracts were selected for further investigation. Eventually, based on the inclusion criteria, eight were eligible for inclusion.

\section{Results}

Two researchers [S.D and M.N] independently screened the titles abstracts and full texts of all retrieved papers, for eligibility. Finally, eight studies were included in the present review that comprised the percentage of victims who had consumed unwillingly ketamine leading to rape [the pertinent data are listed in the Table 1]. Sample size ranged from 23 to 1014 .

Out of the eight included studies three were conducted in the United states of America [9, 10,11]. Only three of the studies reported separate for males and females [10,12,13] . Urine is supported as the best matrix for testing since drug metabolites are detectable for a longer duration. ${ }^{[14]}$ Six studies used urine to test for metabolites in all instances [12, 15,10, 13,7, 16].

In the first article, Scott-Ham \& Burton [16] collected biological samples [blood and/or urine] and analyzed them at the Forensic Science
Service Laboratory in London. This study took place from January 2000 to December 2002. The results showed that among the 1014 victims, ketamine was detected to $0.5 \%$ of them. At the same time, the paper didn't mention the sex and the age of the participants.

Another research that was completed in a Spanish population ${ }^{[15]}$ between January 2010 and December 2013, showed that from the 445 cases, 152 were confirmed as cases of rape. From the 152 confirmed victims, $7.9 \%$ were positive to ketamine. The candidates were mostly women and the average age was 26.2 years. The race of the victims was mentioned in $62.5 \%$ of the cases [ $\mathrm{n}=95$ ], and more specifically $67.3 \%$ [ $n=64]$ of which were Spanish, 26.3\% [n = 25] were from Latin America, while $80.6 \%$ of the total number were victims of foreign origin.

Du Mont et al. ${ }^{[0]}$ conducted a survey reporting cases of rape to seven treatment institutions in Ontario via biological analysis of the samples [oral, vaginal, and/or rectal swabs] for twentytwo months. The study began in June 2005. 977 cases had been reported as DFSA but 882 were examined in this paper. Of the 882 cases, 152 were confirmed as DFSA. The sample was comprised of females of which $60.9 \%$ were employed while at the same time a substantial percentage was students [39.7\%]. 64.7\% identified as White, $4.9 \%$ of the victims were Aboriginal, $4.3 \%$ were Asian, $3.8 \%$ were Latin American, and $2.7 \%$ Black, while the mean age was 25.8 years. The results showed that ketamine was responsible for $2.3 \%$ of the DFSA victims.

Lee et al. completed a research by reviewing anonymous urine samples sent for analysis by the police regarding rapped people that had used drugs [7]. Liquid chromatography tandem mass spectrometry had been used as a method of analysis. This endeavor was unraveled between January 2011 and December 2015. From the 126 anonymous samples, $7.9 \%$ were ketamine-positive. For confidential reasons 
concerning the participants, the gender and the finished in 2015 [11]. The total number of average age were unknown. participants was 23 and all of them were tested

Equally, a retrospective analysis of toxicological findings took place in Las Vegas leading to a statistical interpretation conducted by Paul and Mahesan [11]. The study started in 2000 and positive for drugs' consumption. Of the 23 members, $8.7 \%$ were ketamine-positive and all of them were women, between the age of 20 and 55.

\section{Table 1: Main Results of the Reviewed Studies}

\begin{tabular}{|c|c|c|c|}
\hline Articles & Planning/ Methodology & Participants & Results \\
\hline $\begin{array}{l}\text { Toxicological findings in cases of alleged } \\
\text { drug-facilitated sexual assault in } \\
\text { the United Kingdom over a 3-year } \\
\text { period [2005]. }\end{array}$ & $\begin{array}{l}\text { Collected blood and/or urine } \\
\text { samples and analyzed. } \\
\text { From January } 2000 \text { to December } \\
2002 \text {. }\end{array}$ & $-\mathrm{N}=1014$ & - $0.5 \%$ ketamine. \\
\hline Michael Scott-Ham, Fiona C. Burton. & & & \\
\hline $\begin{array}{l}\text { Alleged drug-facilitated sexual assault in a } \\
\text { Spanish population sample } \\
\text { [2017]. } \\
\text { Carlos García Caballero, Óscar Quintela } \\
\text { Jorge, Angelines Cruz Landeira. }\end{array}$ & $\begin{array}{c}\text { Biological samples [blood and/or } \\
\text { urine] From January } \\
2010 \text { to December } 2013 .\end{array}$ & $\begin{array}{l}-\mathrm{N}=445 \text { received. } \\
-\mathrm{N}=152 \text { confirmed. }\end{array}$ & $\begin{array}{l}\text { - } 7.9 \% \text { ketamine. } \\
\text { - Mostly female population. } \\
\text { - Average age of } 26.2 \text { years. The } \\
\text { race of the victims was } \\
\text { mentioned in } 62.5 \% \text { of } \\
\text { the cases [n }=95] \text {, } \\
67.3 \% \text { [n }=64] \text { of which } \\
\text { were Spanish, } 26.3 \% \text { [n } \\
=25] \text { were from Latin } \\
\text { America, while } 80.6 \% \text { of } \\
\text { the total number were } \\
\text { victims of foreign origin. }\end{array}$ \\
\hline $\begin{array}{l}\text { Drug-facilitated sexual assault in Ontario, } \\
\text { Canada: Toxicological and DNA } \\
\text { findings [2010]. } \\
\text { Janice Du Mont EdD Research Scientist, } \\
\text { Associate Professor, Sheila } \\
\text { Macdonald MN Provincial } \\
\text { coordinator, Nomi Rotbard MPH } \\
\text { Research Associate, PhD } \\
\text { Student, Deidre Bainbridge BSc } \\
\text { Nurse Practitioner, Eriola Asllani } \\
\text { BSc Data Analyst, Norman Smith } \\
\text { PhD Associate Professor, } \\
\text { Marsha M. Cohen. MD Research } \\
\text { Scientist, Professor. }\end{array}$ & $\begin{array}{l}\text { Conducted survey reporting cases } \\
\text { of rape to seven } \\
\text { treatment institutions in } \\
\text { Ontario via biological- } \\
\text { samples analysis [oral, } \\
\text { vaginal, and/or rectal } \\
\text { swabs] for twenty-two } \\
\text { months [starting from } \\
\text { June 2005]. }\end{array}$ & $\begin{array}{l}\text { - } \mathrm{N}=977 \text { report DFSA } \\
-\mathrm{N}=882 \text { in this study } \\
-\mathrm{N}=178 \text { confirmed } \\
\text { Aboriginal [4.9\%], Asian } \\
{[4.3 \%],} \\
\text { Black [2.7\%], } \\
\text { Latin American } \\
{[3.8 \% \text {, and }} \\
\text { White [64.7\%]. } \\
\text { - The sample was } \\
\text { comprised of } \\
\text { females of } \\
\text { which } 60.9 \% \\
\text { were } \\
\text { employed [and } \\
\text { a substantial } \\
\text { percentage } \\
\text { was students } \\
\text { [39.7\%]. }\end{array}$ & $\begin{array}{l}\text { - } 2.3 \% \text { ketamine. } \\
\text { - Mean age: } 25.8 \text { years. }\end{array}$ \\
\hline $\begin{array}{l}\text { Simultaneous drug identification in urine of } \\
\text { sexual assault victims by using } \\
\text { liquid chromatography tandem } \\
\text { mass spectrometry [2018]. } \\
\text { Hei Hwa Lee, Suen Chi Chen, Jong Feng } \\
\text { Lee, Hsin Yu Lin, Bai Hsiun Chen. }\end{array}$ & $\begin{array}{l}\text { Anonymous urine samples were } \\
\text { sent for analysis by the } \\
\text { police concerning rapped } \\
\text { people with the use of } \\
\text { drugs. } \\
\text { Liquid chromatography tandem } \\
\text { mass spectrometry } \\
\text { between January } 2011 \\
\text { and December } 2015 \text {. }\end{array}$ & $\begin{array}{l}\text { - } \mathrm{N}=126 . \\
\text { - Anonymous samples. }\end{array}$ & $-7.9 \%$ ketamine. \\
\hline $\begin{array}{l}\text { Date Rape Drugs in Las Vegas: Detection } \\
\text { After the Fact [2019]. } \\
\text { Paul Anthea, MSc, MD, Mahesan Arnold } \\
\text { MD. }\end{array}$ & $\begin{array}{l}\text { Retrospective analysis of } \\
\text { toxicological findings } \\
\text { leading to a statistical } \\
\text { interpretation } \\
\text { from } 2000 \text { to } 2015 \text {. }\end{array}$ & $\begin{array}{l}\text { - } \mathrm{N}=23 \\
\text { - All female, between } 20 \\
\text { and } 55 \text { years } \\
\text { old }\end{array}$ & - $8.7 \%$ ketamine. \\
\hline $\begin{array}{l}\text { Toxicological findings in } 1000 \text { cases of } \\
\text { suspected drug facilitated sexual } \\
\text { assault in the United States } \\
\text { [2019]. }\end{array}$ & $\begin{array}{r}\text { Collected blood and/or urine was } \\
\text { from } \quad \text { Laboratory } \\
\text { Information Management } \\
\text { System from March } 2015 \\
\text { to June 2016. }\end{array}$ & $\begin{array}{l}-\mathrm{N}=1000 \\
-\mathrm{N}=562: \text { Female. Mean } \\
\text { Age: } 26.8 \\
-\mathrm{N}=51: \text { Male. } \\
\text { Mean age: } 26.52 .\end{array}$ & $\begin{array}{l}\text { - } 0.5 \% \text { ketamine. } \\
\text { - Out of the } 1000 \text { consecutive } \\
\text { cases reviewed, } 784 \\
\text { cases [78.4\%] were } \\
\text { positive for one or more } \\
\text { intoxicating substances. }\end{array}$ \\
\hline $\begin{array}{l}\text { Toxicological Findings in Cases of Sexual } \\
\text { Assault in the Netherlands } \\
\text { [2011]. } \\
\text { Ingrid J. Bosman, Ph.D.; Miranda }\end{array}$ & $\begin{array}{l}\text { Biological samples [blood and } \\
\text { urine samples] from } \\
2004 \text { to } 2006 .\end{array}$ & $\begin{array}{l}-\quad N=132 \\
-N=14 \text { [alcohol } \\
+1 \text { drug]. } \\
-94 \% \text { female. } \\
-6 \% \text { male }\end{array}$ & $\begin{array}{llr}-0.7 \% \text { only ketamine in } 132 \\
\\
\text { participants } \\
\quad-7.1 \% \text { alcohol and } \\
\text { ketamine in } 14 \\
\text { participants. }\end{array}$ \\
\hline
\end{tabular}


Stefania Dermitzaki et al., IJPRR, 2021, 4:52

\begin{tabular}{|c|c|c|c|}
\hline $\begin{array}{l}\text { Verschraagen, Ph.D.; and Klaas } \\
\text { J. Lusthof, Ph.D. }\end{array}$ & & $\begin{array}{c}\text { - Mean age was } 25 \\
\text { years old. }\end{array}$ & \\
\hline $\begin{array}{l}\text { The frequency of polidrug use in a driving } \\
\text { population in Rome [2015]. } \\
\text { Giovanni Michele Lagravinese, Alessia } \\
\text { Mammone, Carla Rossi, Miriam } \\
\text { De Vita, Valeria Marino, } \\
\text { Alessandro Feola, Luigi Tonino } \\
\text { Marsella. }\end{array}$ & $\begin{array}{l}\text { Toxicological tests to victims of } \\
\text { rape at the Hospital of } \\
\text { "San Camillo Forlanini", } \\
\text { from October } 2011 \text { to } \\
\text { August 2012. }\end{array}$ & $\begin{array}{l}\text { - } \mathrm{N}=182 . \\
\text { - Males }=78 \% \text {. } \\
\text { - Females }=22 \% \text {. } \\
\text { - Mean age }=34 \text { years } \\
\text { old. }\end{array}$ & $-4 \%$ ketamine. \\
\hline
\end{tabular}

At the same time, one more analysis reflecting on the relation between ketamine and rape was conducted in the United States ${ }^{[10]}$. In this study, researchers collected blood and/or urine from Laboratory Information Management System. This search began in March 2015 and finished in June 2016. From the 1000 participants, 562 were female with a mean age at 26.8 years and 51 were male with a mean age at 26.52 years. Out of the 1000 consecutive cases reviewed, 784 cases [78.4\%] were positive for one or more intoxicating substances. Ketamine was detected in $0.5 \%$ of the total cases.

Bosman et al. ${ }^{[2]}$ analyzed biological samples [blood and urine] during the years 2004 and 2006. The participants were mostly women [94\%] and the average age was 25 years for both genders. From the 132 participants who were searched $0.7 \%$ appeared to be ketaminepositive only. What is more, 14 participants were searched for combining alcohol with drugs, and $7.1 \%$ of the population was proved to have consumed mixed alcohol and ketamine.

The last study took place in Rome from October 2011 until August $2012{ }^{[13]}$. Toxicological tests [especially urine test] were selected from victims of rape at the Hospital of "San Camillo Forlanini". The total number of participants was $182,78 \%$ of whom were male and $22 \%$ female. The average age was 34 years and the results indicated that $4 \%$ of the population were ketamine-positive.

\section{Discussion}

This study reveals a number of challenges that ought to be mentioned. At a quick glance, most of the victims are women, while a number of articles have studied only female population whose age varies from 20 to 25 approximately.
One possible explanation is the fact that women are physically weaker in comparison to men, by nature. Statistically speaking, women are generally shorter and weight less than men, a condition which, hence, makes them the "ideal victim": A short-height and slim woman that will probably not resist, and even if she does, she will be handled easily. ${ }^{[17]}$ As a result, it would not be a fallacy to claim that women seem to be more susceptible to a sexual attack than men.

Another assumption explaining the above, suggests that a great number of men feel ashamed when it comes to reporting sexual victimization. ${ }^{[18]}$ Men victims don't wish to reveal to anyone -including their personal doctor- such a traumatic experience mainly because they may fear that this incident will stigmatize their future relationships. In other words, a man, who suspects that has been a victim of a rape assault, will probably not proceed for examination because of the prejudice he may encounter. [18]

Data were made available mostly by North American and European sources. This might be the case since countries in these continents seem to be more sensitive with issues referring to drug-related assaults. This leads to the conclusion that DFSA is not a topic concerning the western and developed world only. NGOs and global agents in the health sector are advised to keep track of this phenomenon occurring in Asian and African countries, too. Because, as theory and academia suggest, such phenomena are solved efficiently once they are thoroughly examined. [17,18]

Sexual assaults -as a result of the use of drugsis a dominant issue pertaining to the domain of public health and the extent of this phenomenon needs to be studied more thoroughly 
considering the small number of victims reporting the case to the authorities. The reason why is that the victims seem not to remember the incident or they feel ashamed ${ }^{[19]}$. Ketamine as a rape drug is an emerging issue, the extent of which we do not yet acknowledge.

Despite the presentation of the aforementioned articles, a question that should be bearded in mind is why ketamine has been studied less thoroughly in comparison to other DFSAs. The reason behind this is that ketamine is characterized by a short half-life [three hours] ${ }^{[20]}$ and more precisely "the majority of it is eliminated from the body within twenty-four hours" [21]. Another limitation that leads to the limited research around the topic of ketamine is that clinicians, most of the times cannot recognize ketamine or norketamine [it is a metabolite of ketamine] in urine and blood tests [1].

At the same time, there is a range of features making ketamine the most appropriate drug for committing a sexual assault. It is tasteless, odorless and colorless so, it can be easily added in someone's drink [1]. Moreover, consuming ketamine unwittingly leads to amnesia, hallucinations and out-of-body experiences. Equally, ketamine has a short half-life and as a result, it cannot be detected soon enough while, due to its crystal appearance, clinicians often confuse ketamine with methamphetamine or cocaine ${ }^{[22]}$. For all the above reasons, rapists exploit the effects and traits of ketamine and, thus, perpetrate the "perfect crime".

\section{Conclusion}

In order for this phenomenon to be tackled, the intersectoral cooperation of political entities (elected governments, international organizations) with national health institutions is needed while organizing conferences, seminars, informational fora etc with the contribution of governmental and non-governmental entities, so that citizens can be informed about the hazards following the consumption of ketamine, is a necessity. Moreover, medical and nursing staff at the Emergency Department should be adequately trained to detect and accurately evaluate rape victims for ketamine consumption.

Subsequently, people who suspect that have been sexually assaulted should be strongly encouraged to report their case to the police and proceed to the hospital in order to be examined for the consumption of ketamine. Thus, community based informative programs for the public should be implemented. The interdependence of ketamine and rape represent an emerging problem and an interesting topic of study for future endeavors. To our knowledge, this is the first review on the association between ketamine solely and its use as a rape drug. Further studies focusing on the correlation of these two varieties are proposed not only to enrich the scientific community but also for the benefit of the society in the long term.

\section{Ethical Considerations}

All Ethical procedures were performed

\section{Funding}

No Funding was received for this study

\section{Conflict of Interest}

'Declarations of interest: none'.

\section{REFERENCES}

[1]. Mith KEMS, Arive LISALL, Omanelli FRR. Club drugs : methylenedioxymethamphetamine ,. Am J Heal Pharm. 2002;59:1067-76.

[2]. Li J. The new "Mickey Finn specials"--should GHB and ketamine be banned? J Am Pharm Assoc (Wash) [Internet]. 1999;39(4):442-3. Available from: http://dx.doi.org/10.1016/S10865802(16)30460-0

[3]. Magni PA, Pazzi M, Droghi J, Vincenti M, Dadour IR. Development and validation of an HPLC-MS/MS method for the detection of ketamine in Calliphora vomitoria (L.) (Diptera: Calliphoridae). J Forensic Leg Med [Internet]. 2018;58:64-71. Available from: https://doi.org/10.1016/j.jlm.2018.04.013

[4]. Parsons JT, Grov C, Kelly BC. Club drug use and dependence among young adults recruited through time-space sampling. Public Health Rep. 2009;124(2):246-54.

[5]. Albright JA, Stevens SA, Beussman DJ. Detecting ketamine in beverage residues: Application in date rape detection. Drug Test 
Anal. 2012;4(5):337-41.

[6]. Bows H. Sexual violence. A Companion to Crime, Harm Vict. 2016;205-8.

[7]. Lee HH, Chen SC, Lee JF, Lin HY, Chen BH. Simultaneous drug identification in urine of sexual assault victims by using liquid chromatography tandem mass spectrometry. Forensic Sci Int [Internet]. 2018;282:35-40. Available from: http://dx.doi.org/10.1016/j.forsciint.2017.11.0 06

[8]. Busardò FP, Varì MR, Trana ADI, Malaca S, Carlier J, Di Luca NM. Drug-facilitated sexual assaults (DFSA): A serious underestimated issue. Eur Rev Med Pharmacol Sci. 2019;23(24):10577-87.

[9]. Du Mont J, MacDonald S, Rotbard N, Bainbridge D, Asllani E, Smith N, et al. Drugfacilitated sexual assault in Ontario, Canada: Toxicological and DNA findings. J Forensic Leg Med [Internet]. 2010;17(6):333-8. Available from: http://dx.doi.org/10.1016/j.jflm.2010.05.004

[10]. Fiorentin TR, Logan BK. Toxicological findings in 1000 cases of suspected drug facilitated sexual assault in the United States. Vol. 61, Journal of Forensic and Legal Medicine. 2019. p. 56-64.

[11]. Paul A. Date Rape Drugs in Las Vegas: Detection After the Fact [ 111] Breastfeeding and Marijuana Use: Medical and Ethical Policy Analysis [ 10I ] Maternal Fetal Medicine Resources - Variations Across the Military Health Care System [ 14I ]. 2019;2019

[12]. Bosman IJ, Verschraagen M, Lusthof KJ. Toxicological Findings in Cases of Sexual Assault in the Netherlands*. Vol. 56, Journal of Forensic Sciences. 2011. p. 1562-8.

[13]. Lagravinese G.M., Mammone A., Rossi C., De Vita M., Marino V., Feola A., et al. The frequency of polidrug use in a driving population in Rome [Internet]. Istituto Nazionale per le Malattie Infettive Lazzaro Spallanzani: Prex S.p.A.; 2015. Available from:

https://www.scopus.com/record/display.uri?ei d=2-s2.0-

84928620325\&origin $=$ inward\&txGid=3a3caa eb7831caca1d7e232ea3639d64

[14]. Hadland SE, Levy S. Objective Testing: Urine and Other Drug Tests. Child Adolesc Psychiatr Clin N Am. 2016;25(3):549-565. doi:10.1016/j.chc.2016.02.005

[15]. Caballero CG, Jorge ÓQ, Landeira AC. Alleged drug-facilitated sexual assault in a Spanish population sample. Vol. 4, Forensic
Chemistry. 2017. p. 61-6.

[16]. Scott-Ham M, Burton FC. Toxicological findings in cases of alleged drug-facilitated sexual assault in the United Kingdom over a 3-year period. Vol. 12, Journal of Clinical Forensic Medicine. 2005. p. 175-86.

[17]. Kalra G, Bhugra D. Sexual violence against women: Understanding cross-cultural intersections. Indian J Psychiatry. 2013;55(3):244-249. doi:10.4103/00195545.117139

[18]. Stemple L, Meyer IH. The sexual victimization of men in America: new data challenge old assumptions. $A m \mathrm{~J}$ Public Health. 2014;104(6):e19-e26. doi:10.2105/AJPH.2014.301946

[19]. Costa YR de S, Lavorato SN, Baldin JJCM de C. Violence against women and drugfacilitated sexual assault (DFSA): A review of the main drugs. J Forensic Leg Med. 2020;74(June).

[20]. Carter LP. Potential impact of drug effects, availability, pharmacokinetics, and screening on estimates of drugs implicated in cases of assault. Drug Test Anal. 2011;3(9):586-93.

[21]. Sassano-Higgins S, Baron D, Juarez G, Esmaili N, Gold M. a Review of Ketamine Abuse and Diversion. Depress Anxiety. 2016;33(8):718-27.

[22]. Dinis-Oliveira RJ. Metabolism and metabolomics of ketamine: a toxicological approach. Forensic Sci Res [Internet]. 2017;2(1):2-10. Available from: http://dx.doi.org/10.1080/20961790.2017.128 5219 